\title{
TECHNICAL EFFICIENCY AND IMPLEMENTATION COSTS OF SHEEP IDENTIFICATION SYSTEM
}

\author{
Doi:http://dx.doi.org/10.1590/1809-4430-Eng.Agric.v37n5p1073-1080/2017
}

\section{ALAN C. BEZERRA ${ }^{1 *}$, HÉLITON PANDORFI ${ }^{2}$, FRANCISCO F. R. E CARVALHO ${ }^{2}$, CRISTIANE GUISELINI ${ }^{2}$, THIAGO A. S. DE LIMA ${ }^{2}$}

\author{
${ }^{1 *}$ Corresponding author. Universidade Federal Rural de Pernambuco - Unidade Acadêmica de Serra Talhada/ Serra \\ Talhada - PE, Brasil. E-mail: cezaralan.a@gmail.com
}

\begin{abstract}
The objective of this research was to characterize the efficiency and convenience of sheep identification system and its implementation costs. Therefore we quantified the time for implementation, reading and data transfer to a management program in a manual system (earrings) and electronic system (subcutaneous transponders). Furthermore, it was evaluated the implementation costs of the traceability systems by analysis of the absorption costs and comparison between systems. It was observed that the implementation time for the manual system was shorter $\left(2.2 \mathrm{~s} \mathrm{animal}^{-1}\right)$ than the electronic system $\left(4.67 \mathrm{~s} \mathrm{animal}^{-1}\right)$. As for reading time, the electronic system presented shorter time $\left(2.89 \mathrm{~s} \mathrm{animal}^{-1}\right)$ than the manual system $\left(4.67 \mathrm{~s}_{\text {animal }}{ }^{-1}\right)$. As for the data transfer time, the electronic system also presented shorter time (16 s) than manual system (6 min and $42 \mathrm{~s}$ ). In terms of economic costs, the manual system presented lower implementation costs and lower values per tracked animal to ensure the economic viability. In conclusion, the producer must analyze the context around the production unit to choose the best traceability system.
\end{abstract}

KEYWORDS: animal identification, sheep production, traceability.

\section{INTRODUCTION}

According to data from Food and Agriculture Organization of the United Nations (FAOSTAT, 2013), in 2013, the average annual consumption of goats and sheep in Brazil was 0.62 $\mathrm{kg}_{\text {inhab }}{ }^{-1}$ year while the world average was $1.91 \mathrm{~kg}$ inhab ${ }^{-1}$.year. That is, the market still has great growth potential. However, the expansion of this productive sector in the country has been promoted with the increase consumption of this type of meat in some Brazil regions (Costa et al., 2011). In the northeast region of Brazil, goats and sheep have presented an excellent source of income for producers, due to the good adaptability to the climatic conditions of the region (Farias et al., 2014).

There is still a lack of professionalism, organization and technical assistance in sheep production, so productivity levels are relatively low. Regarding the lack of technical assistance to producers a study by Souza et al. (2012) concluded that scientific production in the area of small ruminants is scarce with greater lack of studies of ambience/well-being/animal behavior, economy/livestock management and forage farming. Regarding the traceability of sheep as business management and organization of the production chain, the situation is still scarce of technical and scientific support.

Several food safety crises reported around the world increased consumer concern (RezendeFilho \& Hurley, 2012). Thus, animal identification whether individual or in group, and its records are the basis for any system of animal traceability, in order to guarantee the confidence of the information and to avoid possible fraud. In this way, we are looking for faster and more effective systems of animal identification, with emphasis on technologies based on radio frequency and its technical and economic aspects of traceability in the production chain (Nassar et al., 2014; Lopes et al., 2013ab).

\footnotetext{
${ }^{2}$ Universidade Federal Rural de Pernambuco/ Recife - PE, Brasil. 
In view of the above, this study aimed to characterize the efficiency and practicality of two identification systems for traceability purposes for sheep production, their technical viability and the costs for the system implementation.

\section{MATERIAL AND METHODS}

The research was carried out in November 2013, in a sheep - producing property located in the municipality of Gravatá - Pernambuco, $8^{\circ} 10^{\prime} \mathrm{S}$ and $35^{\circ} 17^{\prime} \mathrm{W}$, Microregion of the Ipojuca Valley, Agreste (wild area) of the State of Pernambuco. This study consisted of comparison between the electronic identification method with subcutaneous transponders (electronic system) and the identification by visual earrings (manual system), having as evaluation criteria the implementation time, the identification of animal registry, the data transfer and economic viability.

The manual identification system was made using numbered polyurethane earrings, with dimensions of $35 \mathrm{~mm}$ in length and $13 \mathrm{~mm}$ in width. The electronic identification method included a subcutaneous transponder implant, ISO FDX-B, $134.2 \mathrm{KHz}$, with an anti-migration layer (Parylene C), $12 \mathrm{~mm}$ long and $2 \mathrm{~mm}$ in diameter, encapsulated in biocompatible glass.

The research was divided in three stages: 1 - time of identifiers implementation; 2 - time for reading and identification record; 3 - time for data transfer and storage. The methodology was proposed by Lopes et al. (2013a) that evaluated the implementation and reading practicality of conventional and electronic earrings in cattle. Finally, technical-economic feasibility analysis was made for adopted identification technologies.

To record the time of implementation of each identification system, 30 animals were used divided into two groups of 15 individuals with an average age of 60 days. This step was carried out in the maternity of the property and each group received a system of identification: transponder or earrings.

The transponders were applied to the cartilage located at the base of the animal ear with a disposable applicator (Figure A1), as recommended by Caja et al. (1998); while the earrings were attached with applicator pliers (Figure B1). The time was quantified by means of a digital timer with the animals already immobilized from the moment the handler was in front of the animal until the moment of termination of the electronic device injection or the application of the earrings.

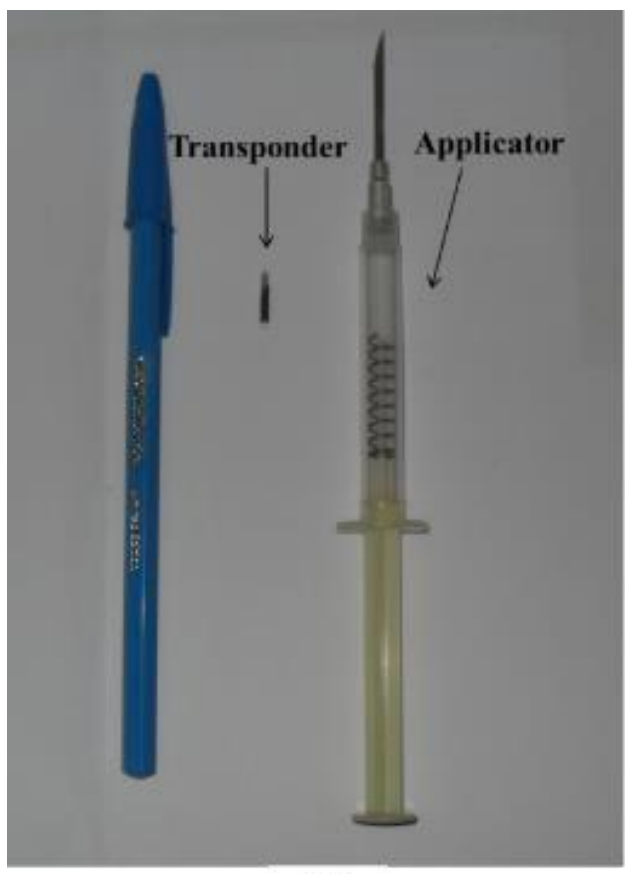

(A)

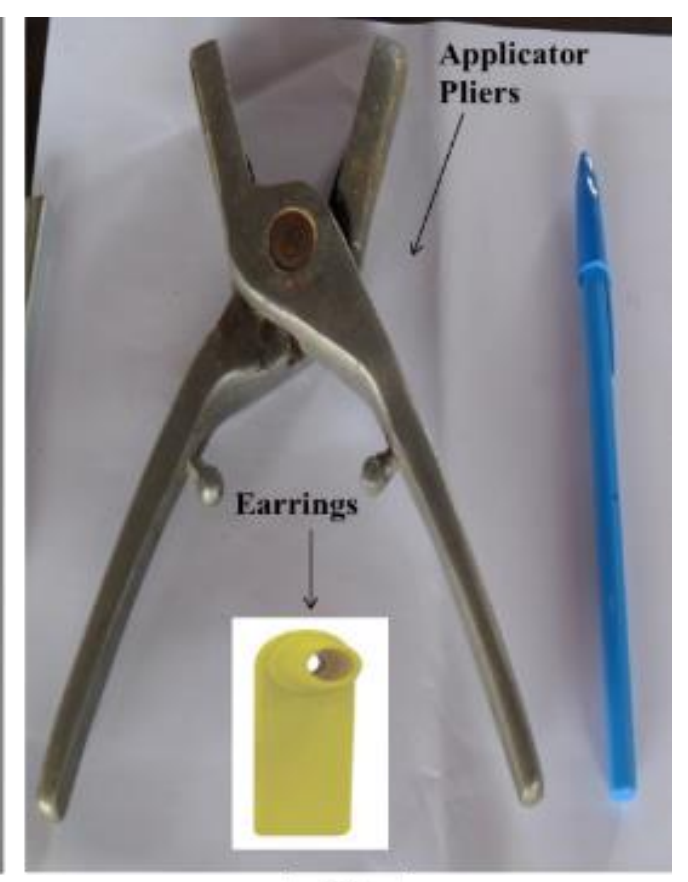

(B)

FIGURE 1. Equipment used to implement the identifiers: transponder and applicator (A); Pliers and identification earrings (B). 
To determine the estimated reading time of the identification systems, simulation was performed with 36 animals divided into two groups of 18 animals, each group with an identification system. The age of the animals in the study was approximately 1 year and they were taken to management trunk to read the identification.

In the group of animals with an electronic system, an individual was responsible for reading the transponder codes by means of the PetScan RT100 V5 - Real Trace portable reader, at mean distance of $10 \mathrm{~cm}$ (Figure 2A) while another individual was responsible for gauging the time needed to identify the animal. The reading time was measured as the handler approached the animal, pressed the "Read" button of the reader until the equipment emitted an audible warning of the transponder reading.

In the group of animals with identification earrings, one individual was responsible for checking the animal earrings number and another was responsible for recording the information in the field book, checking the time for identification and annotation of the data (Figure 2B).The quantification of the time for reading began when the handler approached the animal, read aloud the identification number and finished when the annotation was carried out in the field booklet.

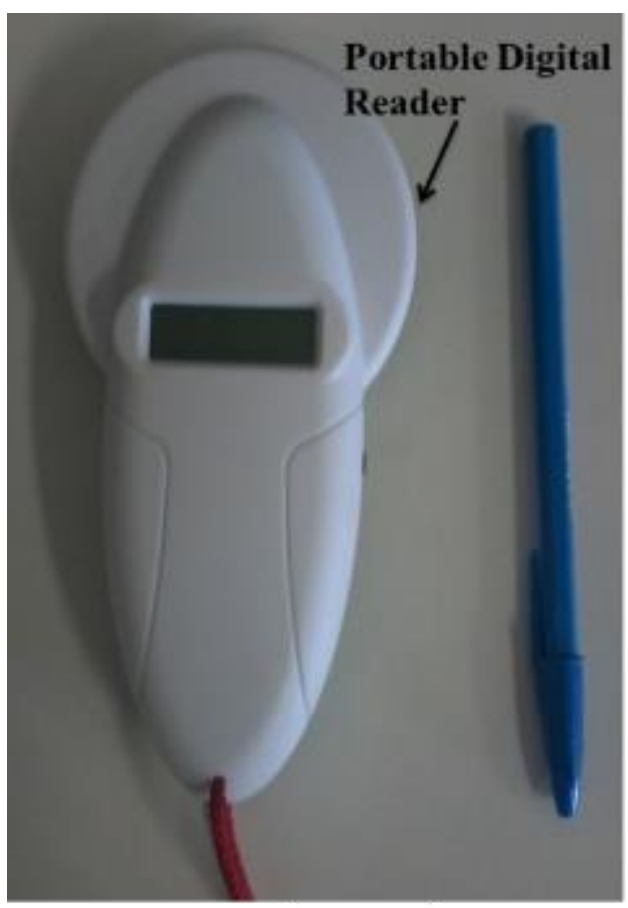

(A)

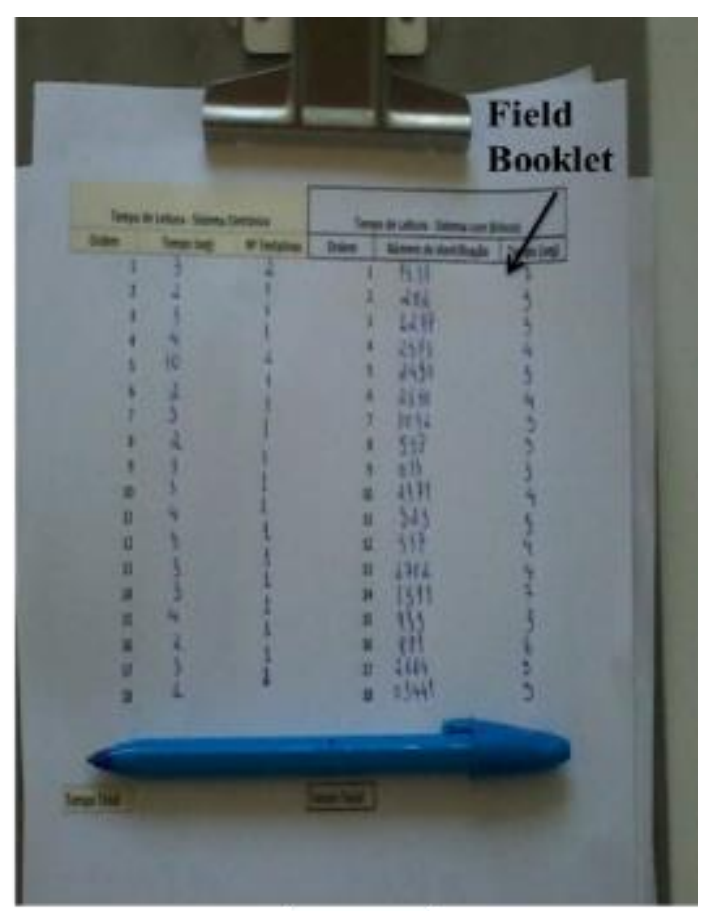

(B)

FIGURE 2. Reading of the identifiers: portable digital reader (A); field booklet (B)

With the field data was carried out the last phase. In this step all the data were inserted in the traceability computational program developed by UFRPE / GPESA. This step was carried out in the property office along with the person responsible for transferring the field data to the computer program database and subsequent generation of the production reports. The quantification of time for the manual system (earrings) occurred from the data entry of the first animal and ended when the identification of the last animal was inserted in the database. The recording of spent time with data transfer from the electronic system occurred from the reader connection to the PC via USB connection cable until the total transfer of data to the computer program.

The data obtained from surveys of the time spent in the study stages were submitted to ANOVA and F test $(\mathrm{P}<0.05)$, using software $\mathrm{R}$ version 2.15.2 (R Core Team, 2013).

The cost analysis of the traceability systems installation was made by adapting the absorption cost method which consisted in the improvement of all cost related to the final product, direct or indirect, fixed or variable, according to Coronetti et al. (2012). Thus, all cost being fixed (technical 
survey, displacement, earrings applicator, reader) or variables (certification fee, earrings and transponders) were absorbed by the final product.

\section{RESULTS AND DISCUSSION}

Figure 3 shows the application moment of the identifiers in the animals, by means of subcutaneous transponder (Figure 3A) and by ear tags of visual identification (Figure 3B).

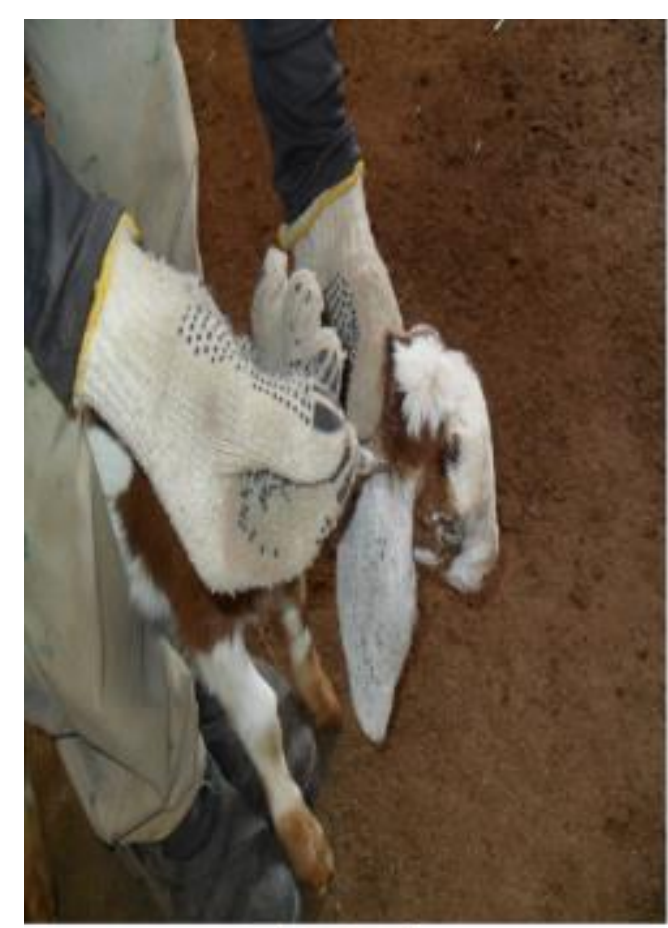

(A)

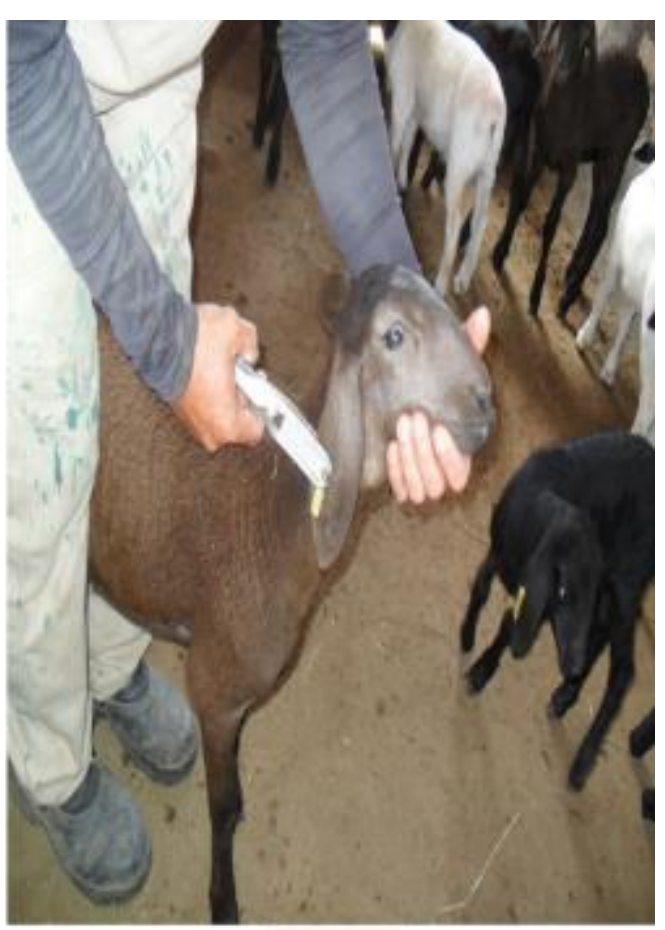

(B)

FIGURE 3. Implementation of the animal identifiers: implementation of the transponder at the base of the animal's ear (A); earring application on the animal (B)

The implementation of the system for identification by earrings is more agile in comparison with the system by transponder. While the system with earrings presents an average of $2.2 \mathrm{~s}$ for implementation, the electronic one takes $4.67 \mathrm{~s}$ (Table 1). This difference in time for transponder application is due to the fact that the handler is more careful that the needle does not hurt the animal or himself, because it is a perforating material. While the application of the earrings is a more rustic procedure, and therefore there is not so much risk for the involved persons.

Other studies point longer time, Klindtworth et al. (1999) pointed out that it took $60 \mathrm{~s}$ for transponder application in cattle and Lopes et al. (2013a) required $47.63 \mathrm{~s}$ for conventional earring application and $49.15 \mathrm{~s}$ for earrings with electronic device. However, all these studies were performed with large animals justifying the demand for superior time on identifiers application.

TABLE 1. Implementation time(s) and reading of electronic and manual identifiers.

\begin{tabular}{ccccccc}
\hline Variable & Method & Total & Average & Standard deviation & CV (\%) & Value P \\
\hline \multirow{2}{*}{ Implementation } & Manual & 33 & $2.2^{* *}$ & 0.56 & 25.4 & \multirow{2}{*}{ ( } \\
& Electronic & 70 & $4.67^{* *}$ & 1.18 & 25.1 & \\
Reading & Manual & 84 & $4.67^{* *}$ & 0.97 & 20.7 & $<0.01$ \\
& Electronic & 52 & $2.89^{* *}$ & 0.68 & 23.4 & \\
\hline
\end{tabular}

Test $\mathrm{F}^{* *}(\mathrm{P}<0.01)$ 
Figure 4A shows the animals' electronic identification registration by reading the transponder by the portable reader while the numbered earrings registration was performed by visual observation of the numbering and annotated in a field booklet (Figure 4B).

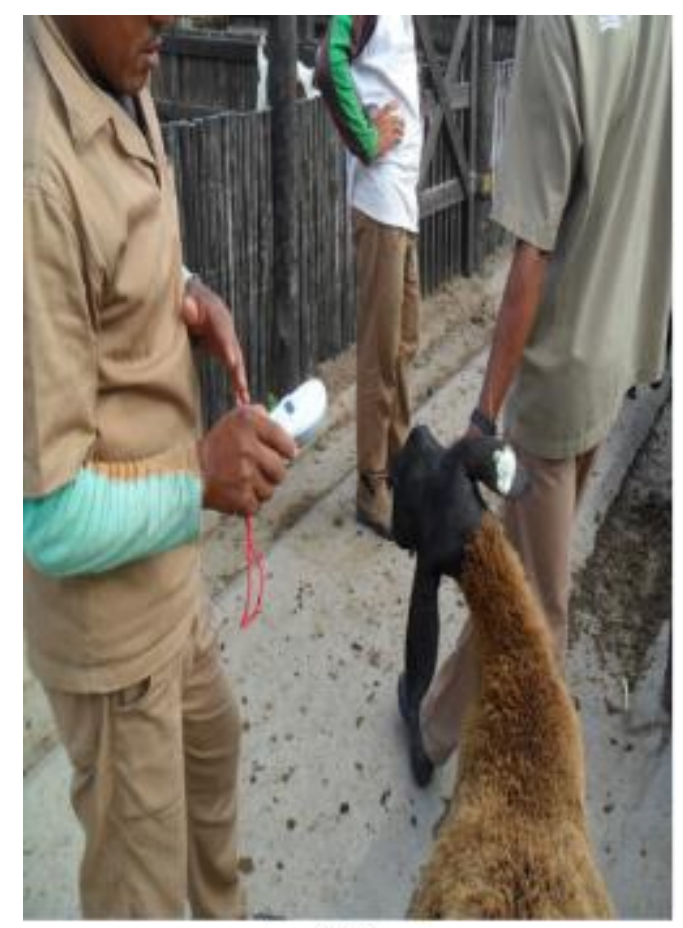

(A)

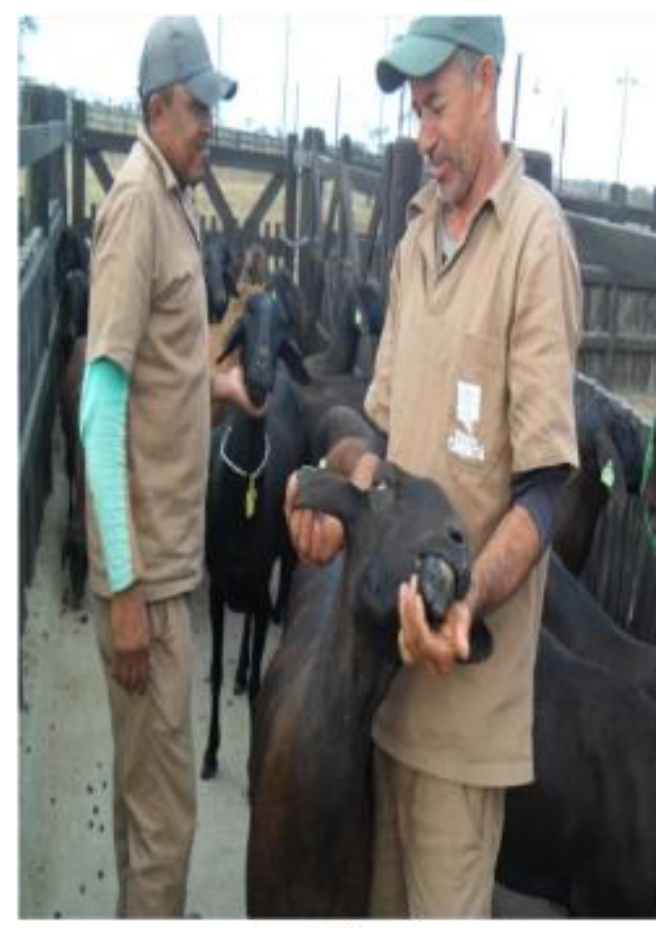

(B)

FIGURE 4. Reading of the identifiers: electronic reading with digital reader (A); manual reading of identification earrings (B).

For identification system reading (Table 1), the electronic system (2.89 s) was more agile compared to the manual system $(4.67 \mathrm{~s})$ (earrings). This is due to the fact that the earrings presented problems of readability due to the conditions of the breeding environment which depreciates the reading quality of the earrings.

The values recorded in this study were also lower than those reported by Klindtworth et al. (1999), in which the mean time to identification read in cattle with an electronic system was $12 \mathrm{~s}$. Differences between reading time can be attributed to differences in animal size. Lopes et al. (2013a) found conventional ear earring reading time 30\% higher than the time required to read the electronic ferrule which also demonstrates the agility of the electronic system front one manual system.

The transfer time of the field data to the computational traceability program was $0 \mathrm{~min} 16 \mathrm{~s}$ for electronic system and $6 \mathrm{~min} 42 \mathrm{~s}$ for the manual system (earrings). The time was lower for the group submitted to the electronic identification system, given that the data was downloaded automatically via USB connection cable between the reader and the PC. On the other hand, the database feeding from the earrings system was manual, in which the responsible person tabulated the data from the field booklet in the control program.

In the case of electronic identification, attention must be paid to quality and agility in the data collection process. It is very common to verify on farms the data recording being done by simple training employees. This leads to possible errors and dubious situations which will later be used in decision making by the manager. In addition to the agility of recording data in the field the accuracy of them and the greater reliability in generation of technical reports are highlighted, based on identification techniques and methodologies developed to mitigate these difficulties (Oliveira \& Almeida, 2013). 
Analysis on Table 2 allows verifying that the cost on implementation of manual system is smaller in relation to the electronic system. Considering a herd of 500 animals it is verified that the cost of the manual system is 2.7 times smaller than the electronic system.

In the manual system for 500 animals, fixed costs accounted for $31.8 \%$ of the total cost. While in the electronic system for the same amount of animals this percentage was about $21.0 \%$ of the total cost. On the other hand, the electronic system presented higher variable cost, due to the high value for acquisition of the transponders used for animal identification.

In both studied systems the cost for traceability implementation reduces as the herd increased, that is, the cost of the traced animal decreases due to the dilution of fixed cost.

TABLE 2. Cost of traceability implementation in different herds in 'Reais' (R\$).

\begin{tabular}{|c|c|c|c|}
\hline Number of Animals & 100 & 300 & 500 \\
\hline \multicolumn{4}{|c|}{ Manual System (Earrings) } \\
\hline Certification & $\mathrm{R} \$ 180.00$ & $\mathrm{R} \$ 540.00$ & $\mathrm{R} \$ 900.00$ \\
\hline Technical Inspection & $\mathrm{R} \$ 600.00$ & $\mathrm{R} \$ 600.00$ & $\mathrm{R} \$ 600.00$ \\
\hline Displacement (visit) & $\mathrm{R} \$ 84.00$ & $\mathrm{R} \$ 84.00$ & $\mathrm{R} \$ 84.00$ \\
\hline Earring & $\mathrm{R} \$ 150.00$ & $\mathrm{R} \$ 450.00$ & $\mathrm{R} \$ 750.00$ \\
\hline Applicator pliers & $\mathrm{R} \$ 85.00$ & $\mathrm{R} \$ 85.00$ & $\mathrm{R} \$ 85.00$ \\
\hline Total & $\mathrm{R} \$ 1,099.00$ & $\mathrm{R} \$ 1,759.00$ & $\mathrm{R} \$ 2,419.00$ \\
\hline Total /Animal & $\mathrm{R} \$ 10.99$ & $\mathrm{R} \$ 5.86$ & $\mathrm{R} \$ 4.84$ \\
\hline \multicolumn{4}{|c|}{ Electronic System } \\
\hline$\overline{\text { Certification }}$ & $\mathrm{R} \$ 180.00$ & $\mathrm{R} \$ 540.00$ & $\mathrm{R} \$ 900.00$ \\
\hline Technical Inspection & $\mathrm{R} \$ 600.00$ & $\mathrm{R} \$ 600.00$ & $\mathrm{R} \$ 600.00$ \\
\hline Displacement (visit) & $\mathrm{R} \$ 84.00$ & $\mathrm{R} \$ 84.00$ & $\mathrm{R} \$ 84.00$ \\
\hline Transponder - Needle & $\mathrm{R} \$ 850.00$ & $\mathrm{R} \$ 2,550.00$ & $\mathrm{R} \$ 4,250.00$ \\
\hline Portable Reader & $\mathrm{R} \$ 690.00$ & $\mathrm{R} \$ 690.00$ & $\mathrm{R} \$ 690.00$ \\
\hline$\overline{\text { Total }}$ & $\mathrm{R} \$ 2,404.00$ & $\mathrm{R} \$ 4,464.00$ & $\mathrm{R} \$ 6,524.00$ \\
\hline Total / Animal & $\mathrm{R} \$ 24.04$ & $\mathrm{R} \$ 14.88$ & $\mathrm{R} \$ 13.05$ \\
\hline
\end{tabular}

Despite of the impact on production cost it is important to highlight that the implementation of a traceability system allows other gains for producers among which we can highlight: greater knowledge of the herd by the producer, opening of new external markets (Lopes et al., 2013b), as well as a possible increase in the meat price (consumer bonus). Thus, the choice of the best technology for traceability implementation should be considered in the context of production.

The manual system presents a lower implementation cost, requires less skilled labor, but is more subject to errors and even fraud which makes the system less reliable (Lopes et al., 2013a). Even with a high implementation cost, the electronic system has great potential for automating processes when coupled with other technologies and computer management programs. Furthermore, according to Nassar et al. (2014) and Silva et al. (2014), the electronic system (RFID) promotes a number of advantages in the management of the production chain, such as better product visibility, increase efficiency and the processes speed, improvement in information accuracy, reduced product stock losses and agility in the real-time information management.

For the traceability implementation in Brazil (SISBOV), some slaughterhouses signaled an additional R\$2.00 per arroba of the traced bovine (Lopes et al., 2008) which can make the implementation of these systems viable. To do so, in goat growing farm further studies are needed to determine the financial viability of more competitive systems in the long term and whether the same additional payment system used for SISBOV can be applied to the traceability of mediumsized animals. 


\section{CONCLUSIONS}

Thus, it can be concluded that the manual identification system is more viable for producers, since it presents the lowest cost value and the shortest time of implementation, even though it has an average reading time of 2 seconds longer than the electronic one. However, other elements should be considered for choosing the animal identification method, since the electronic system presents a shorter data transfer time and greater reliability. In addition, further studies are needed to assess the feasibility of the traceability system for sheep and goat industry sector.

\section{REFERENCES}

Caja G, Ribó O, Nehring R (1998) Evaluation of migratory distance of passive transponders injected in different body sites of adult sheep for electronic identification. Livestock Production Science 55(3):279-289.

Coronetti J, Beuren IM, Sousa MABde (2012) Os métodos de custeio utilizado nas maiores indústrias de Santa Catarina. Gestão.Org - Revista Eletrônica de Gestão Organizacional 10(2). Available: http://www.revista.ufpe.br/gestaoorg/index.php/gestao/article/viewFile/299/236. Accessed: Apr 28, 2014.

Costa RG, Medeiros GRde, Duarte TF, Pedrosa NA, Voltolini TV, Madruga MS (2011) Salted goat and lamb meat: Typical regional product of the city of Petrolina, state of Pernambuco. Small Ruminant Research 98(1):51-54.

FAOSTAT - Food and Agriculture Organization of the United Nations Statistics (2013) Food Supply - Livestock and fish primary equivalent. Available: http://www.fao.org/faostat/en/\#data/CL. Accessed: May 5, 2017.

Farias JLdeS, Araújo MRAde, Lima AR, Alves FSF, Oliveira LS, Souza HAde (2014) Análise socioeconômica de produtores familiares de caprinos e ovinos no semiárido Cearense, Brasil. Archivos de Zootecnia 63(241):13-24.

Klindtworth M, Wendel G, Klindtworth K, Pirkelmann H (1999) Electronic identification of cattle with injectable transponders. Computers and Electronics in Agriculture 24(1):65-79.

Lopes MA, Dores Silva M, Demeu AA, Gomide DR, Bruhn FRP (2013a) Custo da implantação e utilização de dois métodos de identificação de bovinos leiteiros. Revista Ceres 60(6):757-764.

Lopes MA, Ferrazza RA, Bruhn FRP, Demeu AA (2013b) Dificuldades encontradas pelos técnicos de defesa sanitária animal na implantação da rastreabilidade na cadeia produtiva de bovinos de corte no Brasil. Arquivos do Instituto Biológico 80(2):135-144. Available:

http://www.scielo.br/scielo.php?script=sci_arttext\&pid=S1808-

16572013000200001\&lng=en\&nrm=iso. Accessed: Nov 11, 2015.

Lopes MA, Santos G, Amado GB (2008) Viabilidade econômica da adoção e implantação da rastreabilidade em sistemas de produção de bovinos no estado de minas gerais. Ciência e Agrotecnologia 32(1):288-294.

Nassar V, Sampaio TL, Vieira ML (2014) A rastreabilidade aplicada à cadeia de produção agropecuária. Perspectivas em Gestão \& Conhecimento 5(1):98-114. Available:

http://www.okara.ufpb.br/ojs/index.php/pgc/article/view/18408. Accessed: Nov 11, 2015.

Oliveira CA, Almeida JCC (2013). Gestão técnica e financeira aliada a rastreabilidade em pecuária de corte - o caso Fazenda Arural. Revista de Ciências da Vida 33 (1):25-39.

R Core Team (2013) R: A language and environment for statistical computing. R Foundation for statistical computing. Available: http://www.r-project.org/. Accessed: Jan 14, 2014.

Rezende-Filho MA, Hurley TM (2012) Information asymmetry and traceability incentives for food safety. International Journal Production Economics 139(2):596-603. 
Silva DED, Souza EARD, Azevedo LOD, Lasco TDS (2014) A aplicação da tecnologia de identificação por rádio frequência na logística. Revista Computação Aplicada-UnG 3(1):21-27. Available: http://www.revistas.ung.br/index.php/computacaoaplicada/article/viewFile/1948/1543. Accessed: Nov 11, 2015.

Souza D, Stivari T, Paula E, Leitzke N, Gilaverte S (2012) Produção científica nacional relacionada à caprinocultura de corte entre os anos de 2006 a 2010. Synergismus scyentifica UTFPR 7(1).

Available: http://revistas.utfpr.edu.br/pb/index.php/SysScy/article/viewArticle/1508. Accessed: Oct $10,2013$. 